\title{
UJI DAYA HAMBAT EKSTRAK KASAR DAUN JOHAR (Cassia siamea L.) TERHADAP BAKTERI Pseudomonas aeruginosa SECARA IN VITRO
}

\author{
Sri Andayani ${ }^{a}$, Heny Suprastyani ${ }^{a}$, dan Miraleyana ${ }^{a, *}$

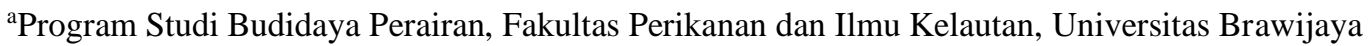 \\ Malang Jl. Veteran No. 1 Malang, Indonesia \\ *Koresponden penulis : miraleyana@student.ub.ac.id
}

\begin{abstract}
Abstrak
Dampak penggunaan antibiotik dapat menyebabkan resistensi terhadap patogen. Alternatif lain perlu dicari untuk mengatasi permasalahan tersebut dengan menggunakan pengobatan bahan alami yang lebih ramah lingkungan. Salah satu bahan alami adalah tanin, alkaloid, saponin dan fenol yang terdapat pada daun johar (Cassia siamea L.). Penelitian ini bertujuan untuk mengetahui pengaruh pemberian ekstrak kasar daun johar yang dapat menghambat pertumbuhan Pseudomonas aeruginosa. Metode yang digunakan adalah metode eksperimental dengan Rancangan Acak Lengkap (RAL), menggunakan Uji MIC (Minimum Inhibition Concentration) dan Uji Cakram. Penelitian ini terdiri dari 5 perlakuan, 2 kontrol dan 3 ulangan. Perlakuan menggunakan ekstrak kasar daun johar (C.siamea L.) dengan dosis 110 ppm, 135 ppm, 160 ppm, 185 ppm dan 210 ppm. Hasil penambahan dosis ekstrak kasar (C. siamea L.) terhadap zona hambat menunjukkan pola linier dengan persamaan $y=8,1725+0,0093 x$ dan $\mathrm{R}^{2}=0,935$. Hasil penelitian menunjukkan ekstrak kasar daun johar $(C$. siamea L.) dapat menghambat pertumbuhan $P$. aeruginosa, sejalan dengan penambahan ekstrak. hal ini dilihat dari meningkatnya diameter rata-rata zona bening sejalan dengan penambahan dosis ekstrak.
\end{abstract}

Keywords: Daun johar, Pseudomonas aeruginosa, Uji MIC, Uji Cakram

\begin{abstract}
The impact of using antibiotics can cause resistance to pathogens. Alternatives used to overcome the problem by changing the treatment of natural ingredients which contains antibacterial active compounds which are more environmentally friendly. One of the natural ingredients is tannin, alkaloid, saponin and phenol found in johar leaves (Cassia siamea L.). this research aims to know the influence of the granting johar leaves crude extract that can inhibit growth $P$. aureginosa. The method used was the experimental method with Completely Randomized Design (CRD), using the MIC test (Minimum Inhibition Concentration) and disc test. This study consisted of 5 treatments, 2 controls and 3 replications. The treatments used the crude extracts of johar leaves at a dose of 110 ppm, 135 ppm, 185 ppm and 210 ppm. The results of addition of the doses of crude extract $C$. siamea $\mathrm{L}$. on inhibition zone showed a linear pattern with the equation $y=8.1725+0.0093 x$ and $\mathrm{R}^{2}=0.935$. The results showed the crude extract of johar leaves could inhibit growth of $P$. aeruginosa, bacteria showed that the average diameter of the clear zone has increase in line with the addition of extracts.
\end{abstract}

Keywords: Johar leaves, Pseudomonas aeruginosa, MIC test, Disc test.

\section{PENDAHULUAN}

Indonesia merupakan kepulauan yang memiliki wilayah sumber daya alam melimpah, diantaranya adalah sumber daya perairan, baik tawar, laut dan payau yang menunjang pembangunan perikanan sehingga dapat meningkatkan devisa negara. Potensi sumber daya kelautan yang dimiliki oleh Indonesia yaitu sumber daya perikanan (tangkap maupun budidaya). Sektor kelautan perikanan merupakan salah satu sumber andalan dalam pembangunan perikanan di Indonesia. Produksi dari perikanan budidaya sendiri secara keseluruhan diproyeksikan meningkat dengan rata-rata $4,9 \%$ per tahun [1].

Peningkatan potensi usaha budidaya menyebabkan tidak terkontrolnya manajemen budidaya, sehingga akan mengakibatkan faktor hama dan penyakit ikan tersebar ke daerah lain yang dapat 
menimbulkan kerugian yang sangat besar. Gangguan terhadap ikan dapat disebabkan oleh organisme lain, pakan maupun kondisi lingkungan yang kurang menunjang dalam sistem budidaya, hal itu menimbulkan serangan penyakit ikan yang adalah hasil interaksi yang tidak serasi antara ikan, kondisi lingkungan dan organisme penyakit. Patogen penyebab timbulnya penyakit pada usaha budidaya adalah bakteri, di antaranya bakteri Pseudomonas aeruginosa. Bakteri ini umumnya hidup di tanah, air tawar dan air limbah [2].

Bakteri $P$. aeruginosa adalah bakteri gram negatif bersifat patogen yang memiliki bentuk batang. Ikan yang terinfeksi menunjukkan gejala klinis luka pada permukaan tubuh dan kulit. Infeksi penyakit ini juga menyebabkan luka pada sirip dan ekor [3]. Karakteristik gejala klinis ditimbulkan oleh bakteri $P$. aeruginosa pada ikan yang terinfeksi adalah pendarahan bagian mulut, operkulum serta bagian sisi perut tubuh [4].

Hingga sekarang penanggulangan yang dilakukan untuk pengobatan bakteri ialah dengan pemberian antibiotik dari bahan kimia. Pemberian antibiotik kimia secara terus menerus dapat mengakibatkan bakteri menjadi resisten. Selain itu, residu dari antibiotik dapat mencemari lingkungan perairan yang menyebabkan penurunan kualitas air. Alternatif yang digunakan untuk mengatasi permasalahan serangan bakteri adalah mengganti penggunaan pengobatan dengan bahan alami. Senyawa bahan aktif pada tumbuhan yang memiliki potensi sebagai antibakteri, salah satunya adalah daun johar (Cassia siamea L.). Tanaman daun johar $(C$. siamea L.) mengandung senyawa aktif seperti saponin, antrakuinon dan alkaloid. Persentase kandungan ekstrak daun johar mengacu pada penelitian [5] aktivitas antioksidan ekstrak daun johar menggunakan pelarut etanol sebesar $90,81 \%$. Mengacu pada hasil penelitian [6] hasil pengamatan diperoleh daya hambat terbesar terdapat pada ekstrak etanol daun johar yang mengandung senyawa alkaloid, flavonoid, saponin dan tanin terhadap bakteri Staphylococcus aureus. Kandungan alkaloid, tanin, saponin dan fenol dalam daun johar memungkinkan ekstrak daun johar berperan sebagai antibakteri.
Dilakukan penelitian ini untuk menjelaskan pengaruh dan menentukan dosis efektif dalam penggunaan ekstrak daun johar (C. siamea L.) terhadap daya hambat pada bakteri $P$. aureginosa.

\section{MATERI DAN METODE}

Penelitian ini dilakukan di Laboratorium Ilmu Teknologi Hasil Perairan Divisi Keamanan Hasil Perikanan dan Laboratorium Eksplorasi Sumber daya Perikanan dan Kelautan Fakultas Perikanan dan Ilmu Kelautan, Universitas Brawijaya, Malang.

Metode penelitian yang digunakan adalah metode eksperimen dengan rancangan penelitian yang digunakan adalah Rancangan Acak Lengkap (RAL). Penelitian terdiri dari 5 perlakuan dan 2 kontrol dengan 3 kali ulangan. Penggunaan perlakuan adalah pemberian ekstrak kasa daun C. siamea L. sebagai uji daya hambat bakteri P.aeruginosa secara in vitro. Perlakuan A (110 ppm), perlakuan B (135 ppm), perlakuan C (165 ppm), perlakuan D (185 ppm), dan perlakuan E (210 ppm). Terdapat perlakuan kontrol positif yaitu Oxytetracycline $30 \mathrm{ppm}$ dan kontrol negatif (tanpa perlakuan).

Alat yang digunakan dalam penelitian ini antara lain: cawan Petri, tabung reaksi, pipet volume, bola hisap, jangka sorong, rotary vacum evaporator, spatula, gunting, vortex mixer, blue tip, laminary air flow, hot plate, lemari pendingin, jarum ose, oven, autoklaf, inkubator, mikropipet, rak tabung reaksi, gelas ukur, beaker glass, pinset, sprayer, nampan, corong kaca, spatula, erlenmeyer, cotton swab, bunsen, botol film, timbangan digital, blender, spektrofotometer, lap kering.

Bahan-bahan yang digunakan pada penelitian ini antara lain: daun johar $(C$. siamea L.), bakteri $P$. aeruginosa, ethanol $96 \%$, Media TSB, Media PSA, Media MHA, DMSO $10 \%$, alkohol $70 \%$, Oxytetracycline, akuades, spirtus, kertas label, kertas saring, kapas, aluminium foil, plastik wrap, benang kasur, tisu, kertas cakram, vaseline, kertas bekas, sarung tangan, korek api.

\section{Pembuatan Ekstrak Kasar Daun Johar (C. siamea L.)}

Metode ekstraksi yang digunakan dalam penelitian ini adalah metode maserasi. 
Maserasi merupakan metode ekstraksi yang paling sederhana yaitu dengan cara merendam serbuk simplisia dalam pelarut. Metode ini tergolong sederhana tetapi telah mendapat bahan aktif simplisia dengan maksimal, serta keuntungan utama dari metode ini tidak dilakukan dengan pemanasan sehingga dapat mencegah rusak atau hilangnya bahan aktif [7]. Daun johar sebanyak 100 gr dimaserasi dengan menggunakan larutan etanol $96 \%$ dengan perbandingan 1:6 selama 24 jam. Hasil maserasi disaring dan dipekatkan menggunakan rotary vacum evaporator dengan rotasi $100 \mathrm{rpm}$ pada suhu $40^{\circ} \mathrm{C}$ sampai mendapatkan hasil ekstrak berupa pasta, lalu hasil ekstrak ditimbang didapatkan sebesar $17,04 \%$.

\section{Pembuatan Media Uji Agar Miring}

Media PSA (Pseudomonas Selective Agar) ditimbang $0,96 \mathrm{~g}$ dengan menggunakan timbangan digital. Media dimasukkan ke dalam Erlenmeyer, kemudian dilarutkan dengan akuades sebanyak $20 \mathrm{ml}$ dan dihomogenkan. Tabung reaksi ditutup kapas dan dibungkus aluminium foil dan plastic wrap. Media disterilisasi dengan autoklaf pada suhu $121^{\circ} \mathrm{C}$ selama 15 menit dengan tekanan $1 \mathrm{~atm}$. Tabung reaksi yang berisi media steril dimiringkan dengan kemiringan $45^{\circ}$ dan ditunggu hingga padat. Media yang telah padat selanjutnya dilakukan strike dalam keadaan steril.

\section{Kultur Bakteri}

Media TSB (Triptic Soy Broth) ditimbang 0,6 gram dengan menggunakan timbangan digital dan dimasukkan ke dalam Erlenmeyer. Media dilarutkan dengan akuades $20 \mathrm{ml}$ lalu dihomogenkan. Media yang sudah homogen ditutup kapas dan ditutup dengan aluminium foil kemudian dibungkus plastic wrap, media disterilisasi dengan autoklaf pada suhu $121^{\circ} \mathrm{C}$ selama 15 menit dengan tekanan $1 \mathrm{~atm}$.

\section{Pembuatan Uji MIC (Minimum Inhibition Concentration)}

Media TSB ditimbang 3 gram dengan menggunakan timbangan digital dan dimasukkan ke dalam Erlenmeyer. Media dilarutkan dengan akuades $100 \mathrm{ml}$ dan dihomogenkan. Setelah homogen, larutan dituang ke dalam 10 tabung reaksi masingmasing sebanyak $10 \mathrm{ml}$. Dosis yang digunakan pada penelitian pendahuluan yaitu berdasarkan log dimulai dari $0,01 \mathrm{ppm}, 0,1$ ppm, 1 ppm, 10 ppm, 100 ppm, 1000 ppm selanjutnya masing-masing tabung reaksi kemudian ditutup kapas dan ditutup dengan aluminium foil kemudian dibungkus dengan plastic wrap, selanjutnya media disterilisasi dengan autoklaf pada suhu $121^{\circ} \mathrm{C}$ selama 15 menit dengan tekanan $1 \mathrm{~atm}$.

\section{Pembuatan Uji Cakram}

Media MHA ditimbang 3,8 gram dengan menggunakan timbangan digital. Media dimasukkan ke dalam Erlenmeyer, kemudian dilarutkan dengan akuades sebanyak $100 \mathrm{ml}$ dan dihomogenkan. Erlenmeyer ditutup kapas dan dibungkus dengan plastik wrap. Media disterilisasi dengan autoklaf pada suhu $121^{\circ} \mathrm{C}$ selama 15 menit dengan tekanan 1 atm. Menyiapkan 5 konsentrasi ekstrak kasar daun johar yang akan diujikan, perlakuan dosis cakram di penelitian ini menggunakan dosis 110 ppm, 135 ppm, 160 ppm, 185 ppm dan $210 \mathrm{ppm}$. Media dituang ke dalam 4 cawan Petri dengan masing-masing cawan diisi $\pm 25 \mathrm{ml}$ yang dilakukan di dalam LAF (Laminary Air Flow) untuk menghindari kontaminasi dan dalam kondisi steril, ditunggu hingga memadat.

\section{HASIL DAN PEMBAHASAN}

\section{Uji MIC (Minimun Inhibition Concentration)}

Uji MIC dilakukan dengan pemberian dosis ekstrak kasar daun johar yang berbeda dengan pelarut akuades steril dan DMSO dengan tujuan untuk mengetahui dosis minimum (terkecil) dalam menghambat pertumbuhan bakteri uji $P$. aeruginosa. Sebelumnya dilakukan penelitian pendahuluan untuk mengetahui dosis daya hambat untuk digunakan dalam penggunaan ekstrak daun johar, adapun dosis yang 
digunakan adalah 1000 ppm, 100 ppm, 10 ppm, $1 \mathrm{ppm}, 0,1 \mathrm{ppm}$ dan 0,01 ppm serta digunakan kontrol positif dengan pemberian antibiotik Oxytetracycline $30 \mathrm{ppm}$. Dosis pada penelitian pendahuluan yang mendekati kontrol positif adalah $100 \mathrm{ppm}$ yang mampu menghambat bakteri $P$. aeruginosa. Pengamatan pada uji MIC tidak hanya dilakukan dengan indikator nilai absorbansi akan tetapi juga dilihat dari perubahan warna pada masing-masing tabung. Diperkuat dengan pernyataan [8], Indikator minimum inhibitory concentration ditentukan berdasarkan hasil pengamatan timbulnya warna kekeruhan atau kejernihan pada berbagai konsentrasi. Warna kejernihan seluruh konsentrasi pada tabung reaksi dibandingkan dengan kontrol, kejernihan tiap konsentrasi yang mendekati kontrol positif menyatakan bahwa perlakuan ekstrak mampu menghambat pertumbuhan bakteri.

Berdasarkan dosis tersebut dilakukan uji MIC ke-2 dengan dosis yang kisarannya lebih besar hal ini memungkinkan dengan dosis dinaikkan mampu lebih menghambat $P$. aeruginosa. Berikut hasil pengamatan uji MIC ke-2 berdasarkan tingkat absorbansi disajikan pada Tabel 1.

Tabel 1. Hasil Pengamatan Uji MIC.

\begin{tabular}{cccc}
\hline No. & $\begin{array}{c}\text { Konsentrasi } \\
(\mathbf{p p m})\end{array}$ & Absorban & Warna \\
\hline 1. & 100 & 0,171 & $\begin{array}{c}\text { Hampir } \\
\text { Bening }\end{array}$ \\
\hline 2 & 110 & 0,167 & Bening \\
3 & 120 & 0,159 & Bening \\
4 & 130 & 0,154 & Bening \\
5 & 140 & 0,150 & Bening \\
6 & 150 & 0,147 & Bening \\
7 & 160 & 0,142 & Bening \\
8 & 170 & 0,130 & Bening \\
9 & 180 & 0,126 & Bening \\
10. & 190 & 0,122 & Bening \\
11. & K $(+)$ & 0,169 & Bening \\
12. & K $(-)$ & 0,735 & Keruh \\
\hline
\end{tabular}

\section{Keterangan:}

Kontrol (+) : Oxytetracycline 30 ppm

Kontrol (-) : tanpa pemberian ekstrak

Berdasarkan hasil pengukuran nilai absorbansi menggunakan spektrofotometer dengan panjang gelombang $570 \mathrm{~nm}$. Dosis MIC yang digunakan yaitu 110 ppm karena nilai absorbansi mendekati nilai kontrol positif dan warna media dalam tabung juga menunjukkan terjadi perubahan warna bening. Hasil dosis yang didapat $110 \mathrm{ppm}$ ini akan digunakan sebagai dosis untuk uji dilusi agar, dosis tersebut merupakan dosis terkecil dalam menghambat pertumbuhan bakteri $P$. aeruginosa. Hasil uji MIC berdasarkan tingkat kekeruhan dapat dilihat pada Gambar 1.

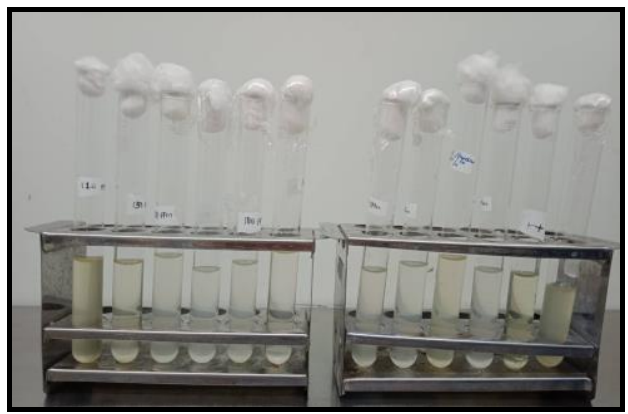

Gambar 1. Hasil Uji MIC

Terdapatnya senyawa aktif antibakteri pada ekstrak kasar daun johar (C. siamea L.) yang mampu menghambat pertumbuhan bakteri $P$. aeruginosa. Sesuai dengan pernyataan [9], Adapun komponen fitokimia utama dari daun johar (C. siamea L.) adalah saponin, antrakuinon, alkaloid, tannin.

\section{Uji Cakram}

Perlakuan dosis pada uji cakram di penelitian ini menggunakan dosis $110 \mathrm{ppm}$, 135 ppm, 160 ppm, 185 ppm dan 210 ppm, kontrol positif dan kontrol negatif. Pemberian dosis ini didapatkan dari uji MIC sebesar 110 ppm yang telah mampu menghambat pertumbuhan bakteri P. aeruginosa. hasil gambar uji daya hambat bakteri $P$. aeruginosa setelah pemberian ekstrak kasar daun johar (C. siamea L.) disajikan pada Gambar 2.

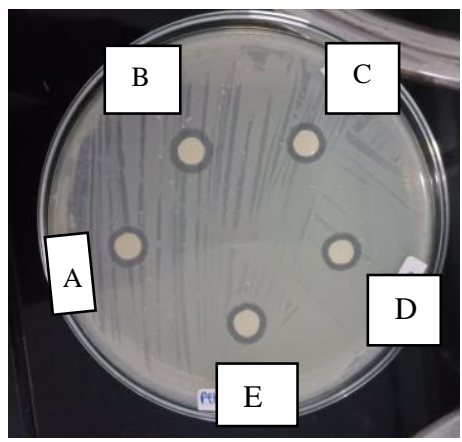

Gambar 2. Hasil Uji Cakram 
Hasil pengamatan yang dilakukan selama inkubasi 24 jam dalam inkubator dengan suhu $32^{\circ} \mathrm{C}$ dilakukan pengukuran menggunakan jangka sorong (mm), selanjutnya didapatkan hasil rata-rata diameter zona bening perlakuan ekstrak kasar daun johar (C. Siamea L.). Disajikan pada Tabel 2.

Tabel 2. Hasil Rata - Rata Zona Hambat Bakteri

\begin{tabular}{cc}
\hline $\begin{array}{c}\text { Konsentrasi } \\
\text { Ekstrak (ppm) }\end{array}$ & $\begin{array}{c}\text { Rata-rata Diameter Zona } \\
\text { Hambat }(\mathbf{m m})\end{array}$ \\
\hline A (110) & $9,22^{\mathrm{a}}$ \\
B (135) & $9,40^{\mathrm{a}}$ \\
C (160) & $9,69^{\mathrm{b}}$ \\
D (185) & $9,89^{\mathrm{c}}$ \\
E (210) & $10,14^{\mathrm{d}}$ \\
\hline
\end{tabular}

Berdasarkan hasil di atas, hasil rata - rata zona hambat yang tertinggi yaitu perlakuan dengan konsentrasi ekstrak 210 ppm sebesar $10,14 \mathrm{~mm}$, sedangkan rata - rata diameter zona bening terendah diperoleh konsentrasi ekstrak 110 ppm sebesar 9,22 mm.

Hubungan antara konsentrasi ekstrak daun johar (C. siamea L.) dengan zona hambat yang diperoleh dari hasil analisis regresi disajikan berupa grafik yang dapat dilihat pada Gambar 3.

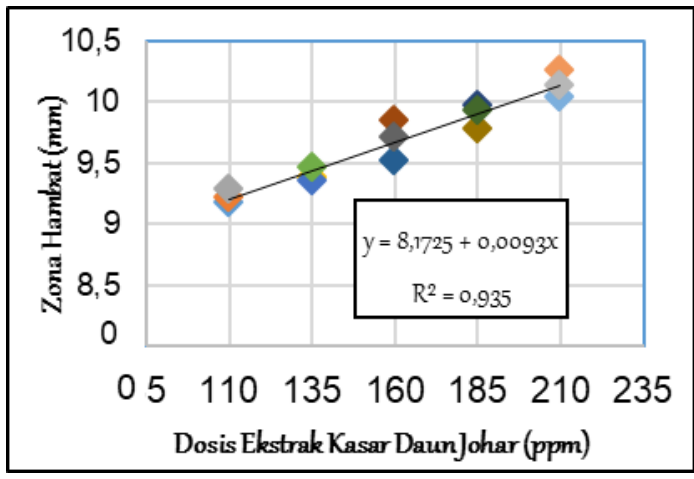

Gambar 3. Grafik Hubungan Zona Hambat

Berdasarkan Gambar 3, menjelaskan bahwa hubungan antara penambahan pemberian dosis ekstrak kasar daun johar (C. siamea L.) terhadap nilai diameter zona hambat menunjukkan grafik linier dengan persamaan $\mathrm{y}=8,1725+0,0093 \mathrm{x}$ dan nilai koefisien $\mathrm{R}^{2}=0,935$. Pemberian perlakuan ekstrak kasar daun johar (C. siamea L.) untuk menghambat pertumbuhan bakteri $P$. aeruginosa menyatakan adanya respon yang meningkat seiring dengan bertambahnya pemberian dari dosis perlakuan
Hasil uji MIC dan uji cakram yang telah dilakukan menunjukkan bahwa ekstrak daun johar (C. siamea L.) mampu menghambat pertumbuhan bakteri $\mathrm{P}$. aeruginosa hal tersebut dapat dilihat dari zona bening yang terbentuk. Kandungan senyawa aktif seperti tanin, alkaloid, saponin dan fenol berperan penting dalam menghambat pertumbuhan $\mathrm{P}$. aeruginosa.

Aktivitas senyawa aktif alkaloid pada ekstrak kasar daun johar (C. siamea L.) memiliki mekanisme kerja dengan cara berinteraksi dengan dinding sel yang menyebabkan kerusakan dinding sel. Alkaloid juga dapat berikatan dengan DNA bakteri yang menyebabkan kegagalan sintesis protein [10]. Dikutip dari [11], Kandungan aktif saponin merupakan senyawa yang dapat membentuk busa dan merusak membran sel karena bisa membentuk ikatan dengan lipida dari membran sel. Saponin bekerja sebagai antibakteri dengan mengganggu stabilitas membran sel bakteri sehingga menyebabkan sel bakteri lisis atau senyawa saponin akan merusak membran sitoplasma dan membunuh sel membran sitoplasma. Pada golongan kandungan aktif fenol memiliki mekanisme kerja dengan cara menembus dan merusak dinding sel kemudian mengendapkan protein sehingga menjadi racun dalam protoplasma sel bakteri. Fenol dapat menyebabkan cairan sel bakteri keluar (lisis), maka senyawa bahan aktif masuk ke dalam sel bakteri, mengakibatkan terjadi kebocoran metabolit esensial yang dibentuk oleh bakteri serta merusak permeabilitas membran sel [12].

\section{KESIMPULAN}

Pada penelitian mengenai uji daya hambat ekstrak kasar daun johar (C. siamea L.) terhadap bakteri $P$. aeruginosa secara in vitro diperoleh kesimpulan bahwa pemberian perlakuan ekstrak kasar daun johar (C. siamea L.) berpengaruh terhadap daya hambat bakteri $P$. aeruginosa. dosis ekstrak kasar yang memiliki zona hambat tertinggi pada penelitian ini sebesar 210 ppm dengan rata-rata diameter $10,14 \mathrm{~mm}$.

\section{DAFTAR PUSTAKA}


[1] Mulyani, Y., Bachtiar, E dan Agung, M. U. K, "Peranan senyawa metabolit sekunder tumbuhan mangrove terhadap infeksi bakteri Aeromonas hydrophila pada ikan Mas (Cyprinus carpio L.)" Jurnal Akuatika, vol. 4, no. 1, hal. 1-9, Mar 2013.

[2] Kurniawan. A, "Penyakit Akuatik," UBB Press, hal. 1-225, Mar 2012.

[3] Wajdi, S. A., Kasmiyati, S dan Hastuti, S. P, "Uji aktivitas antibakteri campuran ekstrak biji kelor (Moringa oleifera) dan daun kersen (Muntingia calabura) terhadap Pseudomonas aeruginosa dan Bacillus subtilis," Journal of Tropical Biodiversity and Biotechnology, vol.2, hal. 10-15, Jun 2017.

[4] Hossain, M. I., Neela, F. A., Hussain, M. A., Rahman, M. H dan Suzuki, S, "Distribution of $P$ aeruginosa in Swamps and its Infection to $O S$ niloticus," Journal of Bio-Science, vol. 14, no. 1, hal. 77-81, Nov 2006.

[5] Ratu, A. P dan Bunjamin, F. S, “ Aktivitas antioksidan ekstrak air, etanol 96\%, etil asetat dan N-Heksana daun johar (Cassia siamea L.) dengan metode pengangkal radikal bebas DDPH," Journal University Research Colloqium (URECOL), vol.9, no.1, hal. 353-360, Okt 2019.

[6] Fitriah, F., Mappiratu, M., dan Prismawiryanti, P. " Uji aktivitas antibakteri ekstrak daun tanaman johar (Cassia siamea L.) dari beberapa tingkat kepolaran pelarut," KOVALEN: Jurnal Riset Kimia, vol. 3, no.3, hal.242-251. Des. 2017.

[7] Sa'adah, $\mathrm{H}$ dan Nurhasnawati, $\mathrm{H}$, "Perbandingan pelarut etanol dan air pada pembuatan ekstrak umbi bawang tiwai (Eleutherine Americana Merr) menggunakan metode maserasi," Jurnal Ilmiah Manuntung, vol. 1, no. 2, hal. 149-153, Jan 2017.
[8] Vifta, R. L., Khotimah, S. K dan Luhurningtyas, F. P, " Uji Aktivitas Antifungi Ekstrak Etanol Biji Timun Suri (Cucumis melo L.) terhadap Pertumbuhan Candida albicans secara In Vitro," Indonesian Journal of Pharmacy and Natural Product, vol 1,hal.10-17,Feb 2018.

[9] Phaiphan, A., Baharin, B. S., Tan, C. P., Rahman, R. A dan Ganesan, P, "Antioxidant and antibacterial activities of different solvent extractions from cassia siamea (Lamk.) leaves," Journal of Chemical and Pharmaceutical Research, vol.6, hal. 655-662, Apr 2014.

[10] Putri, R. R., Hasanah, R dan Kusimaningrum, I, "Uji aktivitas antibakteri dan Uji fitokimia ekstrak daun mangrove Sonneratia alba," Aquawarman Jurnal Sains Dan Teknologi Akuakultur,vol.2, hal.43-50, Apr 2016.

[11] Barodah, L. L., Sumardianto, S dan Susanto, "Efektivitas Serbuk Sargassum Polycystum Sebagai Antibakteri Pada Ikan Lele (Clarias Sp.) Selama Penyimpanan Dingin," Jurnal Pengolahan dan Bioteknologi Hasil Perikanan,vol. 6, hal. 10-20, Nov 2016.

[12] Nopandi, H., Pratama, R. I., Suryana, A. A. H dan Rostini, I, "Penambahan Ekstrak Kunyit Terhadap Karakteristik Presto Ikan Nila yang Disimpan Pada Suhu Kamar," Jurnal Perikanan Kelautan,vol.2,hal.50-55,Des 2019. 